DOI 10.31558/2519-2949.2019.2.5

УДК 340:355.01

ORCID ID: https://orcid.org/0000-0001-9749-7559

Щебетун І. С., Донецький національний університет імені Василя Стуса

ORCID ID: https://orcid.org/0000-0002-1129-2470

Міхайліна Т. В., Донецький національний університет імені Василя Стуса

\title{
ЗАХИСТ ПРАВ ДІТЕЙ НА ОКУПОВАНИХ ТЕРИТОРІЯХ: МІЖНАРОДНИЙ ДОСВІД ТА УКРАЇНСЬКІ РЕАЛІЇ
}

\begin{abstract}
У статті досліджується проблема захисту прав дітей на окупованих територіях та під час збройних конфліктів.

Виявлено, що діти відносяться до найбільш уразливих категорій населення, чиї права повсякчасно порушуються під час воєнних дій та збройних конфліктів, причому особливо актуалізується ия проблема на окупованих територіях.

Встановлено, щзо нормативна база Украйни щодо забезпечення прав дітей на окупованих територіях та під час збройних конфліктів, потребує суттєвого удосконалення, оскільки їх статус окреслено в загальних рисах, без реального змістовного наповнення. Процедура отримання статусу $\epsilon$ забюрократизованою, що обумовлює небажання осіб його отримувати.

Актуальною проблемою є захист прав та водночас визначення меж настання відповідальності дітей-комбатантів. Також конкретизаиії потребують організаційні засади, зокрема, форми та способи захисту прав дітей на окупованих територіях та під час воєнних дій $і$ збройних конфліктів.

У статті зроблено висновок, щуо для забезпечення ефективного виконання обов'язків відповідних державних інституиій щодо дітей, які перебувають у зоні воєнних дій $і$ збройних конфліктів, дочільно розширити співпраџю держави з відповідними неурядовим організаціями та іншими складовими частинами громадянського суспільства. Крім того, підлягають удосконаленню норми чинного законодавства, які закріплюють правовий статус дітей, які постраждали внаслідок воєнних дій $і$ збройних конфліктів: він потребує конкретизаиії, уточнення та «наповнення» фактичними можливостями і пільгами. Важливим також вбачається спрощення бюрократичних процедур, пов'язаних із отриманням даного статусу, та безперешкодна реалізація дитиною прав $i$ можливостей, що ним передбачені.
\end{abstract}

Ключові слова: діти, права дітей, захист дітей, забезпечення прав дітей, окупована територія, збройний конфлікт, воєнні дії.

Діти - це окрема, самостійна частина суспільства, якій притаманні особливі правила поведінки. Воєнні дії в Україні та соціально-економічна нестабільність спричиняють напругу в суспільстві, у тому числі й у дитячому середовищі. Унаслідок свого становища діти потребують особливого підходу, соціального захисту та поваги до їх прав. На жаль, в сучасному українському суспільстві його бракує, i соціальний захист в багатьох випадках лише задекларований в нормативних документах, але внаслідок браку коштів та бюрократії $є$ неадресним та неефективним.

На даний момент відсутня єдина скоординована соціальна політика відносно захисту прав дітей на окупованих територіях; немає консолідованої статистичної бази щодо жертв війни, передусім, дітей, $з$ початку бойових дій (2014 року), а також відсутній чіткий механізм надання їм відповідного соціального статусу i адекватної соціальної допомоги. Більшість ініціатив у цій сфері $\epsilon$ ситуативними і неефективними. Захист прав дітей на окупованих територіях потребує нормативно забезпеченого механізму та надання реальної допомоги, чітко визначеного статусу дітей, які проживали/проживають на окупованих територіях та під час збройного конфлікту; окремого порядку відшкодування завданої шкоди здоров'ю під час військових дій. Вищезазначене й обумовлює важливість й актуальність представленої статті.

Окремі аспекти дослідження проблем захисту прав дитини були предметом розгляду вченими різних галузей права, зокрема, Андрусишина Б.І., Волинець Л.С., Кочемировської О.О., Крестовської Н.М., Мордань О.О., Оніщенко Н.М., Пономаренко О.В., Савельєва Н.М., Чубук Р.В., Чернета С.Ю. та інших. Але, незважаючи на гостроту зазначеної проблеми, на сьогоднішній день

(C) Щебетун I. C., Міхайліна Т. В., 2019 
у вітчизняній юридичній науці недостатньо досліджень, присвячених дослідженню проблем захисту прав дитини в умовах збройного конфлікту в Україні.

Мета статті - сформулювати пропозиції та рекомендації щодо удосконалення організаційноправових засад захисту прав дітей на окупованих територіях та під час збройних конфліктів.

Першим документом, який офіційно закріпив права дитини, була Загальна Женевська декларація, прийнята в 1924 році Лігою Націй. Декларація закріпила базові гуманні принципи.

У 1959 році ООН затвердила Декларацію прав дитини, яка розширила перелік прав дітей [1]. В подальшому зазначені положення знайшли своє закріплення у Конвенції про права дитини 1989 року [2]. Згодом прийнято Факультативний протокол 2000 р. до Конвенції про права дитини щодо участі дітей у збройних конфліктах [3].

Конвенція про права дитини була ратифікована Україною у 1991 році, іiі положення мають неухильно дотримуватися і знайшли відображення унаціональному законодавстві, зокрема, передбачені Конституцією України (статті 24, 51, 52), Сімейним кодексом України (глави 13, 14), Законами України «Про охорону дитинства», «Про забезпечення організаційно-правових умов соціального захисту дітей-сиріт та дітей, позбавлених батьківського піклування», «Про основи соціального захисту бездомних осіб і безпритульних дітей». Крім того, Кримінальним кодексом України та Кодексом України про адміністративні правопорушення дитина визнається особливим об'єктом, що захищається державою.

Не зважаючи на існування значної кількості нормативно-правових актів, що регулюють різні аспекти захисту прав дітей, за даними Гельсінської спілки, «сьогодні дуже мало правових норм, які встановлюють особливості правового регулювання права дітей в умовах збройного конфлікту» [4, с. 28].

У 2014 р. прийнято Закон України «Про забезпечення прав і свобод громадян та правовий режим на тимчасово окупованій території України», норми якого містять лише загальні, недеталізовані положення щодо соціально-правового захисту дітей під час збройного конфлікту.

Відповідно до Указу Президента України «Про невідкладні заходи щодо забезпечення додаткових соціальних гарантій окремих категорій громадян» від 29 жовтня 2014 року звернено увагу на необхідність вирішення питання щодо навчання дітей учасників бойових дій і дітей, батьки яких загинули під час участі в антитерористичній операції [5].

До 2016 року фактично єдиною спеціальною правовою нормою, що врегульовувала статус дитини в умовах збройного конфлікту, було положення статей 30-33 Закону України «Про охорону дитинства», які не відповідали ситуації, що склалася в Україні.

Задля вдосконалення системи забезпечення прав дітей в Україні шляхом удосконалення механізмів та процедур прийняття рішень щодо захисту дитини за місцем ії фактичного перебування, розвитку соціальних послуг з підтримки сімей із дітьми, які потрапили в складні життєві обставини, постраждали внаслідок воєнний дій чи збройних конфліктів Верховною Радою України 26 січня 2016 року прийнято Закон України «Про внесення змін до деяких законів України, спрямованих на посилення соціального захисту дітей та підтримки сімей $з$ дітьми». А 5 липня 2017 року уряд України ухвалив постанову №268 про надання дітям статусу постраждалих внаслідок воєнних дій [6].

Таким чином, можна дійти висновку, що права дітей в Україні нормативно визначені досить широко, разом з тим, у даній сфері існує чимало проблем:

- залишається відкритим питання щодо належного правозастосування та притягненням до відповідальності винних осіб за недотримання законодавства із захисту прав дітей;

- моніторинг дотримання українського законодавства в сфері захисту прав дітей на окупованих територіях Криму та окремих районів Донецької та Луганської областей не проводиться, на що неодноразово зверталась увага, у тому числі, і під час Парламентських слухань на тему: «Права дитини в Україні: забезпечення, дотримання, захист»;

- до цього часу найменше підтримки з боку держави отримують діти, що були поранені під час бойових дій, які втратили годувальника чи батьків або отримали інвалідність внаслідок військових дій і які зазнали найбільших страждань від бойових дій;

- діти, які проживають у «сірій зоні» та поблизу проведення військових дій у Донецькій, Луганській областях та суміжних районах, потребують особливого піклування. За даними ЮНІСЕФ, зараз близько 200 тисяч дітей у віці до 18 років проживають на відстані 15 кілометрів по обидва боки від лінії розмежування. Це діти, які кожного дня бачать своїми очима зброю, чують постріли, ховаються у школі у бомбосховища під час бомбардувань, але наперекір всьому навчаються. Це діти 
війни, які ростуть і формуються під час війни. Для багатьох з них наслідками збройного конфлікту $\epsilon$ втрата батьків, психологічні травми, стреси, розірвання сімей, переїзд, розірвання стосунків 3 друзями.

Розглядаючи правову суть питання, слід зазначити, що нещодавно до Закону «Про охорону дитинства» внесли нову категорію дітей: дитина, яка постраждала внаслідок воєнних дій і збройних конфліктів - дитина, яка внаслідок воєнних дій чи збройного конфлікту отримала поранення, контузію, каліцтво, зазнала фізичного, сексуального, психологічного насильства, була викрадена або незаконно вивезена за межі України, залучалася до участі у військових формуваннях або незаконно утримувалася, у тому числі в полоні», а також доповнили зазначений Закон статтями 30 «Заборона участі дітей у воєнних діях і збройних конфліктах» та 30-1 «Захист дітей, які перебувають у зоні воєнних дій і збройних конфліктів, та дітей, які постраждали внаслідок воєнних дій і збройних конфліктів».

Разом $з$ тим, наразі законодавством не визначено питання щодо пільг дитини, яка постраждала внаслідок воєнних дій і збройних конфліктів. Оскільки статус має право отримати дитина, яка зареєстрована як внутрішньо переміщена особа, то всі права, що визначені Законом «Про забезпечення прав і свобод внутрішньо переміщених осіб» [7] розповсюджуються на дітей цієї категорії. Крім того, не вирішено питання дітей, які проживають (перебувають) на підконтрольній Україні території, де виникли обставини, зазначені в статті 1 вищевказаного Закону: «негативні наслідки збройного конфлікту, тимчасова окупація, повсюдні прояви насильства, порушень прав людини та надзвичайні ситуації природного чи техногенного характеру». Крім того, отримання зазначеного статусу пов'язано з численними бюрократичними перепонами і враховуючи відсутність його змістовного наповнення, зрозумілими стають причини небажання осіб отримувати статус дитини, яка постраждала внаслідок воєнних дій і збройних конфліктів: станом на 1 вересня 2018 року цей статус отримали всього 0,18 \% дітей від тієї кількості, що мають право на його отримання [8].

Також цим статусом не охоплюються всі аспекти шкоди, від яких може потерпати дитина, яка знаходиться на території збройного конфлікту. Тому Н.В. Лесько запропоновано поряд із категорією «діти, які постраждали внаслідок воєнних дій і збройних конфліктів» закріпити категорію «діти, що перебувають у зоні збройного конфлікту» [9, с. 163]. 3 такою позицією можна погодитися, уточнивши конструкцію «діти, що перебувають/перебували у зоні збройного конфлікту», оскільки навіть знаходження певний час на території воєнних дій накладає величезний відбиток на психіку дитини та їі подальше життя.

Хоча інституції громадянського суспільства та міжнародні неурядові організації намагаються привернути увагу до проблеми захисту прав дітей під час збройних конфліктів та надати інформаційну і методичну допомогу, на сучасному етапі організаційні засади роботи із дітьми 3 числа внутрішньо переміщених осіб якісно не покращилися. Так, ще у 2016 році Даньською радою у справах біженців та Ла Страда - Україна було проведено спільний тренінг для державних службовців у соціальній сфері з надання послуг внутрішньо переміщеним особам, де, в тому числі, розглядалися ризики для дітей в зоні конфлікту, наслідки знаходження там та особливості роботи 3 такими дітьми [10]. Проте, аналізуючи фактичну ситуацію, рекомендації так і не було втілено у практичну діяльність.

Уваги потребують і факти використання дітей у військовому конфлікті і пов'язаних з ним діях (допомога з облаштуванням блок-постів, виконання прохань військових, пов'язаних з несенням служби, та ін.). Однак, в чинному законодавстві відсутнє поняття «залучення дитини у збройний конфлікт», що згідно з прийнятим у міжнародному праві визначенням не обмежено прямою участю у бойових діях, а відноситься до будь-якого використання дітей збройними силами або угрупуваннями. Проте, у Кримінальному Кодексі України також немає визначення залучення (втягнення) дитини у збройний конфлікт (збройні сили/угруповання), як злочину [11].

Невизначеним залишається питання щодо співвідношення норм національного та міжнародного права про те, що діти, втягнуті у військовий конфлікт, не несуть відповідальності за вчинені дії, причому конвенційно під дітьми найчастіше розуміється особа у віці до 18 років. Кримінальним же кодексом України (ст. 22) передбачено діяння, за які кримінальна відповідальність настає 3 14-ти років, зокрема, певні з них можуть вчинятися під час воєнних дій.

На підставі викладеного можна зробити висновок, що забезпечити безумовну реалізацію чинних норм у зоні збройних конфліктів досить складно, а то й взагалі неможливо, враховуючи конкретні обставини на територіях, де державні органи України тимчасово не здійснюють або здійснюють не в повному обсязі свої повноваження. Для ефективного виконання обов'язків щодо дітей, які 
перебувають узоні воєнних дій, доцільно розширити співпрацю держави з відповідними неурядовим організаціями та іншими складовими частинами громадянського суспільства та сприяти їм у проведенні відповідної діяльності.

Крім того, підлягають удосконаленню норми чинного законодавства, щодо правового статусу дітей, які постраждали внаслідок воєнних дій і збройних конфліктів. Він потребує конкретизації, уточнення та «наповнення» фактичними можливостями і пільгами. Важливим також вбачається спрощення бюрократичних процедур, пов'язаних із отриманням відповідного статусу та безперешкодна реалізація дитиною прав і можливостей, що ним передбачені.

\section{Бібліографічний список:}

1. Декларація прав дитини від 20 листопада 1959 року. URL: http://zakon3.rada.gov.ua/laws/show/995_384 (дата відвідування 25.05.2019).

2. Конвенція про права дитини від 20 листопада 1989 року. URL: http://zakon3.rada.gov.ua/laws/show/995_021 (дата відвідування 24.05.2019).

3. Факультативний протокол до Конвенції про права дитини щодо участі у збройних конфліктах від 01 січня 2000 року. URL: http://zakon3.rada.gov.ua/laws/show/995_795 (дата відвідування 30.05.2019).

4. Дитинство під прицілом: права дитини в умовах збройних конфліктів на сході України. За ред. А. П. Бущенка. Українська Гельсінська спілка з прав людини. Київ: КИТ, 2016. 82 с.

5. Про невідкладні заходи щодо забезпечення додаткових соціальних гарантій окремих категорій громадян: Указ Президента України від 29 жовтня 2014 року, № 835/2014. Офіційний вісник України. 2014. № 88. Ст. 2516.

6. Про затвердження Порядку надання статусу дитини, яка постраждала внаслідок воєнних дій та збройних конфліктів. URL: https://zakon.rada.gov.ua/laws/show/268-2017-\%D0\%BF (дата відвідування 02.06.2019).

7. Про забезпечення прав і свобод внутрішньо переміщених осіб: Закон України від 20 жовтня 2014 року (у редакції від 27.03.2018). Відомості Верховної Ради Украӥни. 2015. № 1. Ст. 1.

8. 0,18\%. Саме стільки дітей отримали статус постраждалих внаслідок військових дій. URL: http://radnyk.org/noviny/0-17-same-stilki-ditey-otrimali-status-postrazhdalih-vnaslidok-viyskovih-diy/ (дата відвідування 09.06.2019).

9. Лесько Н.В. Проблеми захисту дітей від насильства під час воєнних дій та збройних конфліктів. Науковий вісник Ужгородського національного університету. Серія «Право». 2017. Вип. 46. Т.1. С. 161-164.

10. Особливості захисту дітей в умовах збройного конфлікту на сході України: вразливість дітей, які $\epsilon$ внутрішньо переміщеними особами. Київ, 2016. 77 с.

11. Захист прав дітей під час збройного конфлікту на території Східної України: проблема правової визначеності. URL: http://ukrainepravo.com/international_law/public_international_law/zakhyst-prav-ditey-pid-chaszbroynogo-konfliktu-na-terytoriyi-skhidnoyi-ukrayiny-prob̄lema-pravovoyi-/ (дата відвідування 08.06.2019).

\section{References:}

1. Deklaratsia prav dytyny vid 20.11.1959. URL: http://zakon3.rada.gov.ua/laws/show/995_384 (25.05.2019).

2. Konventsia pro prava dytyny vid 20.11.1989. URL: http://zakon3.rada.gov.ua/laws/show/995_021 (24.05.2019).

3. Fakultatyvnyi protokol do Konventsii pro prava dytyny shhodo uchasti u zbroinykh konfliktax vid 01.01.2000. URL: http://zakon3.rada.gov.ua/laws/show/995_795 (30.05.2019).

4. Dytynstvo pid prytsilom: prava dytyny v umovakh zbroinyh konfliktiv na shodi Ukrainy. Za red.

A. P. Bushhenka. Ukrainska Helsinska spilka z prav liudyny. Kyiv: KIT, 2016. $82 \mathrm{s.}$

5. Pro nevidkladni zahody shhodo zabezpechennia dodatkovykh sotsialnykh harantii okremyh katehorii hromadian: Ukaz Prezydenta Ukrainy vid 29.10.2014. Ofitsiinyi visnyk Ukrainy. 2014. № 88. St. 2516.

6. Pro zatverdzhennia Poriadku nadannia statusu dytyny, yaka postrazhdala vnaslidok voiennyh dii ta zbroinyh konfliktiv. URL: https://zakon.rada.gov.ua/laws/show/268-2017-\%D0\%BF (02.06.2019).

7. Pro zabezpechennia prav i svobod vnutrishnio peremishenyh osib: Zakon Ukrainy vid 20.10.2014. Vidomosti Verkhovnoi Rady Ukrainy. 2015. № 1. St. 1.

8. $0,18 \%$. Same stilky ditei otrymaly status postrazhdalyh vnaslidok viiskovyh dii.

URL: http://radnyk.org/noviny/0-17-same-stilki-ditey-otrimali-status-postrazhdalih-vnaslidok-viyskovih-diy/ (09.06.2019).

9. Lesko N.V. Problemy zahystu ditei vid nasylstva pid chas voennyh dii ta zbroinyh konfliktiv. Naukovyi visnyk Uzhgorodskoho natsionalnoho universytetu. Seria «Pravo». 2017. Vyp. 46. T.1. S. 161-164.

10. Osoblyvosti zahystu ditei v umovah zbroinoho konfliktu na shodi Ukrainy: vrazlyvist ditei, yaki ye vnutrishnio peremishenymy osobamy. Kyiv, $2016.77 \mathrm{~s}$.

11. Zahyst prav ditei pid chas zbroinoho konfliktu na terytorii Shidnoi Ukrainy: problema pravovoi vyznachenosti. URL: http://ukrainepravo.com/international_law/public_international_law/zakhyst-prav-ditey-pidchas-zbroynogo-konfliktu-na-terytoriyi-skhidnoyi-ukrayiny-problema-pravovoyi-/ $(0 \overline{8} .06 .2019)$. 


\section{Shchebetun I. S., Mikhaylina T. V. Protection of children's rights in the occupied territories: international experience and Ukrainian realities}

The article investigates the problem of protection of children's rights in the occupied territories and during armed conflicts.

It is revealed that children belong to the most vulnerable categories of the population, whose rights are constantly violated during military operations and armed conflicts, and this problem is especially urgent in the occupied territories.

It is noted that the normative base of Ukraine, which concerns the rights of children in the occupied territories and during armed conflicts, requires significant improvement, since the status of the rights of children affected by military action and armed conflict is outlined only in General terms, without real content. The procedure for obtaining it is bureaucratic, which leads to the reluctance of persons to obtain the appropriate status. The protection of rights and, at the same time, the delineation of the limits of responsibility of child combatants is a pressing issue. The institutional framework for the protection of children's rights in the occupied territories also needs to be established.

The article concludes that in order to ensure the fulfillment of the relevant obligations in respect of children in the zone of military action and armed conflict, it is advisable to expand the cooperation of the state with the relevant non-governmental organizations and other components of civil society. In addition, the norms of the current legislation, which enshrine the legal status of children affected by war and armed conflict, should be improved. It needs to be specified, clarified and «filled» with actual opportunities and benefits. It is also important to simplify the bureaucratic procedures associated with obtaining this status, and the unimpeded implementation of the child's rights and opportunities that they provide.

Key words: children, rights of children, protection of children, ensuring children's rights, occupied territory, armed conflict, military action. 